\author{
Research Article
}

\title{
Proteus Looks Around: Agency, Time, and Context in a Gig Economy Career Analysis
}

Marcia Cristiane Vaclavik ${ }^{1}$ Sidinei Rocha-de-Oliveira ${ }^{1}$ Andrea Poleto Oltramari ${ }^{1}$

\footnotetext{
${ }^{1}$ Universidade Federal do Rio Grande do Sul, Porto Alegre, RS, Brazil
}

Received 15 September 2020. This paper was with the authors for one revision. Accepted 01 June 2021.

First published online 25 June 2021.

Editor-in-chief: Carlo Gabriel Porto Bellini (10) (Universidade Federal da Paraíba, João Pessoa, PB, Brazil); Ivan Lapuente Garrido (1D (Universidade do Vale do Rio dos Sinos, Brazil)

Associate editor: Ana Heloisa da Costa Lemos (1D (Pontifícia Universidade Católica do Rio de Janeiro, IAG, Rio de Janeiro, RJ, Brazil)

Reviewers: Elza Fátima Rosa Veloso (D) (Fundação Instituto de Administração, São Paulo, SP, Brazil) and one anonymous reviewer

Editorial assistants: Kler Godoy and Simone Rafael (ANPAD, Maringá, PR, Brazil) 


\begin{abstract}
Contemporary career studies based on the protean career theory emphasize individual characteristics such as adaptability and flexibility. However, it is important to consider elements that permeate and influence the individual's agency and career paths. This study analyzes how the perspectives of time and context, in addition to the individual's agency, influence the career paths of gig economy workers. The qualitative analysis of data collected from interviews with 57 Brazilian app-based drivers enabled developing an empirically based typology with eight workers' profiles and different ways of adaptation, including how they experience the activity and how they redirect their professional paths. Although adaptability marks their career trajectory, the time and context limit the area in which they can work and exercise agency. This study joins a broader movement in the career field and international studies that seek a better understanding of the gig economy and its consequences. The emergence of app-based activities resulting from a particular time and technological context brings different ways to adapt and change career plans.
\end{abstract}

Keywords: gig economy; contemporary careers; career ecosystem; app-based drivers; labor market

JEL Code: J24, J46, J82, M19. 


\section{INTRODUCTION}

Technology and social changes affect the world of work by continually presenting challenges and opportunities. Occupations emerge, change, and disappear, and people have to adapt to stay in the labor market. The current versatility in the organization of work (International Labour Organization [ILO], 2018b) affects the labor market dynamics and how workers build, transform, and maintain their individual paths (Baruch, 2015). Since the 1980s, labor market movements have intensified, becoming increasingly dynamic, flexible, and deregulated (Baruch, 2015; Mayrhofer, Meyer, \& Steyrer, 2007).

The remarkable technological expansion has enabled the growth of activities mediated by platforms connecting supply and demand - a phenomenon known as 'gig economy' or 'platform economy' -, which is expected to continue in the next few years (Balliester \& Elsheikhi, 2018; Codagnone, Biagi, \& Abadie, 2016). The gig economy is anchored in freelancing activities, where workers operate autonomously as self-employed or micro-entrepreneurs (Balliester \& Elsheikhi, 2018). It is a good example of a non-traditional organization of work, expressed in activities such as app-based private passenger transport (e.g., Uber, Cabify) and delivery services (e.g., Uber Eats, Rappi, and iFood), which have grown substantially in recent years.

The presence of traditional careers in the labor market has declined in the last decades (Barcuh, 2015; Briscoe, Hall, \& DeMuth, 2006), and career success became a personal more than an organizational responsibility (Hall, 2004), fueling "a more individualized career orientation" (Baruch \& Rousseau, 2019, p. 2). The capacity for personal transformation is the main idea of the protean career theory (Baruch \& Vardi, 2016; Briscoe, Hall, \& DeMuth, 2006; Hall, 1996; 2004), which is based on the individuals' adaptation in a self-directed approach. As highlighted by Hall (2004), the "need for people to be more protean in our current business environment" (Hall, 2004, p. 3) fits this new era of massification of freelance work.

Although the protean career theory has gained ground by focusing on individual action and considering time and context as secondary elements, it is crucial to recognize that labor markets are a dynamic and complex system of interconnected and interdependent individuals, organizations, and societies that act at local, regional, sectoral, national, and global levels (Baruch, 2015). In addition, the contextual and historical characteristics of the market structure (Mayrhofer et al., 2007), economic situation, and regulatory system influence the formation of multiple labor markets in countries and regions (Atkinson, 1988), and factors such as access to education, degree of diversity, gender, race, and generation "shape and structure career transitions" (Briscoe et al., 2018, p. 122). Therefore, there are limits to the individual's space of action and capacity to envision career prospects, and biological time (age and life expectancy) and historical time (technological, economic, social, and political moment in the country or region) that mark the individuals' possibilities of experiencing their careers (Orlikowski \& Yates, 2002; Reiss, Schiffinger, Mayrhofer, \& Rapp, 2020).

On the other hand, much of the literature on the gig economy focuses on the micro level (i.e., the workers' profile or motivation) or the macro level (i.e., the causes for the emergence of the
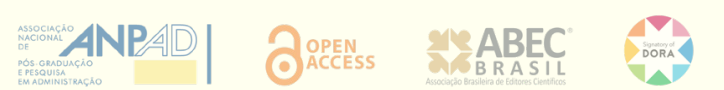
gig economy and its consequences in a societal perspective) (Hofer, Spurk, \& Straub, 2021). There is little information about how these micro and macro levels are interconnected and influence each other. Thus, this study addresses the following question: How can the analysis of the gig economy through an ecosystem perspective encompassing the interrelation between the focus on micro and macro levels contribute to understanding the phenomenon in-depth? In other words, how can the heterogeneity of the gig economy workers and the influence of agency, time, and contexts in the individuals' path help us to understand such an economy better?

Thus, 'the main objective of this study is to analyze how the perspectives of time and context, in addition to the individual's agency, influence the career paths of workers in a gig economy activity.' We argue that specific technological conditions - characteristics of a particular historical time - associated with the local particularities that govern labor relations influence the individuals' agency in their career paths.

The study on how individuals manage their careers in the emerging gig economy - particularly regarding the practice of non-traditional activities in less-favored countries and middle-income economies (Briscoe et al., 2018; Tran, Baruch, Bui, 2019) - could help build a more inclusive body of knowledge in the field of careers. It could also broaden the understanding of the gig economy, self-employment dynamism, and other forms of work organization. Thus, this research presents three theoretical contributions. First, it is part of a broader movement of contemporary studies in the field of careers, which intends to find out how circumstantial elements, such as time and context, could influence career paths (Briscoe et al., 2018; Gunz \& Mayrhofer, 2018). Second, this research contributes to several international studies that seek a better understanding of the gig economy and its consequences for the new ways of working. Because this research unifies studies on career and gig economy, it contributes to expanding knowledge about the impacts of forms of work organization on the individual workers' career paths. Finally, the third theoretical contribution refers to the emergence of app-based driver activity as a result of a particular time and technological context, bringing different ways to adapt and change career plans. Such practices vary according to agency skills - i.e., job values, life, opportunities, and level of education identified - and also to the experiences marked by historical time and context that frame the career trajectories of individuals.

This study points out a tendency for the so-called platform labor to grow continuously and strengthen the importance of algorithmic management in labor relations (Bucher, Schou, \& Waldkirch, 2021; Walker, Fleming, \& Berti, 2021), recognizing that careers and career management are becoming complex and challenge issues (Baruch \& Vardi, 2016). This study addresses these issues by offering practical and managerial contributions for administration and human resources management (HRM), seeking to expand the understanding of the gig economy. 


\section{THEORETICAL FRAMEWORK}

\section{Contemporary career theories and the need to look beyond individual agency}

The protean career is "driven by the person, not the organization, and that will be reinvented by the person from time to time, as the person and the environment change" (Hall, 1996, p. 8). This concept was introduced by Hall (1976) in the 1970s when the author pointed out changes in the direction of organizational careers. Since the 1990s (Hall, 1996), the idea has gained prominence, becoming one of the central theories in career studies in recent decades (Baruch \& Vardi, 2016; Briscoe, Hall, \& DeMuth, 2006; Sullivan \& Baruch, 2009). The protean career theory "represents a self-directed perspective when looking at careers, providing an action guide" (Briscoe, Hall, \& DeMuth, 2006, p. 8). It is conceptualized as "a career in which the person is (1) values-driven in the sense that the person's internal values provide the guidance and measure of success for the individual's career; and (2) self-directed with regard to personal career management - having the ability to be adaptive in terms of performance and learning demands" (Briscoe, Hall, \& DeMuth, 2006 , p. 8). In protean careers, individuals are expected to develop these both meta-competencies - adaptability and identity - to continuously learn and adjust to the demands of a fast-changing world (Hall, 2004). Developing only one of these two meta-competencies can lead to paralysis, evasion, reactivity, rigidity, and dependence, among other consequences (Briscoe \& Hall, 2006; Hall, 2004).

A common feature of many contemporary career theories is the entrepreneurial quality of individuals as the driving forces behind their careers. Workers are expected to "show high levels of agency, i.e., the ability to act on one's own behalf in times of change" (Waters, Briscoe, Hall, \& Wang, 2014, p. 411), and involves both values-driven and self-directed attitudes (Briscoe, Hall, $\&$ DeMuth, 2006). The individuals are responsible for their employability, regardless of their willingness, preparedness, or contextual changes that are not under their control. The responsibility for finding a job and (re)modeling the career rests exclusively on their shoulders, with personal and even organizational consequences that can vary between unhappiness, inefficiency, or even misconduct (Baruch \& Vardi, 2016).

It is known that the ways in which people conduct their careers are marked and shaped by both individual differences and macro contexts (Briscoe et al., 2018; Mayrhofer et al., 2007). The context is a structure that limits and imposes adaptation needs. The 'space' where individuals experience their career is delimited and formed by multiple aspects manifesting at different levels (Mayrhofer et al., 2007). Legal, political, educational, and socioeconomic statuses, as well as gender, race, age, and generation, are considered contextual factors that impact careers, influence attitudes and behaviors, and act as powerful forces that help shape individual careers (Briscoe et al., 2018; Reiss et al., 2020).

Baruch (2015) points out that careers are "part of a wide ecosystem that operates across internal and external labor markets" (Baruch, 2015, p. 364). In the career ecosystem theory's viewpoint, the supply and demand across individuals, institutions, and societies - the three main actors of the ecosystem - manage to meet the needs and requirements around career building (Tran et al., 
2019). The recognition of the existence of "interaction, interdependence and interrelatedness between individuals and their context" (Tran et al., 2019, p. 4) allows us to analyze careers in dynamic labor markets from multiple perspectives (Baruch, 2015; Baruch \& Rousseau, 2019; Guo \& Baruch, 2020). Thus, while some people are pulled to career self-management, others are pushed away, reflecting both the bright and dark sides of career building. These push and pull dynamics represent the interaction between the external environment and the human agency (Tran et al., 2019).

\section{Time and context dimensions and their importance in career understanding}

According to Gunz and Mayrhofer (2015), more comprehensive views on careers consider the context and the time in history in addition to the actor's agency. Context, time, and actor's agency are instances intertwined and mutually dependent so that career changes occur, over time, within a "bounded social space" (Gunz \& Mayrhofer, 2015, p. 4). Parasuraman, Greenhaus, and Linnehan (2000) point out that time is a scarce resource with many dimensions that have an essential role in shaping individuals' career experiences. It crosses professional relationships between individuals and organizations in many ways - such as work schedules and shifts, the mode of compensation (hourly or salaried), and the worker's classification (full-time or part-time employees). Beyond a measure of efficiency and productivity, though, time is an essential aspect of career understanding. For Gunz and Mayrhofer (2015), the temporal perspective is linked to the dimensions of context (space) and the actors' individualities. Transitions and changes in these two perspectives require time, and it is through these changes that the context and the actors' individualities are recorded. "Studying careers from a temporal perspective, then, is a process of tracking, over time, changes in condition and transitions across boundaries" (Gunz \& Mayrhofer, 2015, p. 6).

Although much of the career literature uses frameworks centered on the individual perspective (Briscoe et al., 2018; Mayrhofer et al., 2007), careers can be seen as a "tension between freedom and determinism, between agentivity and structure" (Janand, 2020, p. 16), from an individual and a collective notion (Gunz \& Mayrhofer, 2018). According to Mayrhofer et al. (2007), the careers' context should be understood as a set of environmental factors that influences (a) the work context, which includes the external labor market and social relationships, new forms of work organization, and the economic and institutional environment; (b) the context of origin, related to class and social origin, work history, and educational socialization; (c) the context of society and culture, which addresses topics like gender, ethnicity, and demographic and community factors; and (d) the global context such as internalization and virtualization.

Thus, considering that (1) "career is the evolving sequence of a person's work experiences over time" (Arthur, Hall, \& Lawrence, 1989, p. 8), and (2) "careers are always careers in context" (Mayrhofer et al., 2007, p. 1), we emphasize the importance of time and context dimensions and the myriad of working possibilities that cross a worker's life. We argue that career studies have to consider the interrelation between micro and macro levels of analysis and go beyond examining traditional professions and occupations. This research analyzes the heterogeneity of the gig economy workers using the marks of agency, time, and the context in their individual path,

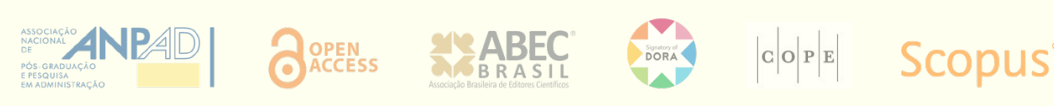


seeking to understand this contemporary phenomenon better. In the next section, we explore some concepts related to the gig economy and digital labor markets.

\section{The gig economy and work in digital labor markets}

Activities that comprise the gig economy - also known as platform economy - were initially considered under the sharing economy umbrella, separated later due to seminal conceptual differences. The gig economy is a working arrangement in which a platform operates via the internet and connects suppliers to demanders of a given service, therefore structuring a market (ILO, 2018a). The main assets in this relation are time and skills (Balaram, Warden, \& WallaceStephens, 2017). By facilitating peer-to-peer transactions, the gig economy reduces costs and makes buying and selling processes more accessible and cheaper (Codagnone, Abadie, \& Biagi, 2016; De-Stefano, 2017; Peticca-Harris, DeGama, \& Ravishankar, 2018; Sundararajan, 2016).

The gig economy reinvents and reconfigures the relationships among consumers, producers, and property (Peticca-Harris et al., 2018) and, consequently, the labor market. Workers are not employees, but freelancers, performing and being compensated for (micro) tasks on demand and in short-term contracts. Although gigs are not new, as they have existed for decades and are very common in certain occupations and professions (e.g., in the field of music or journalism), this format is now enhanced through technological advances, reaching other areas. Thus, its importance for the discussion of new labor standards is undeniable and has been pointed out by many studies worldwide, which makes this phenomenon a topic of growing interest in international research.

These forms of organizing work activities, especially those linked to a more significant intensification of flexibility, blur the boundaries between self-employment and wage employment (ILO, 2018a). This uncertainty often manifests in imprecise conceptualization and lack of a classification of employment type. It creates difficulties in analyzing a phenomenon that is present in social reality and plays an essential role in understanding the future of work and the way people manage their career paths.

Several studies have sought to understand the gig economy movement in the labor sphere. Although a secure, regular, and full-time job linked to one employer through a contract has been the rule for decades, it no longer represents the way many people have been earning a living (Manyika et al., 2016). The 'uberization' of the labor relations (Codagnone, Biagi, \& Abadie, 2016; Degryse, 2016; Fleming, 2017; Schmidt, 2017; Valenduc \& Vendramin, 2016) is at the center of controversies and economic and judicial disputes. It raises concerns among theorists and practitioners since the implications of uberization for the economy and the world of work, including the impacts on the career trajectories, are not yet fully understood (Codagnone, Biagi, Abadie, 2016).

Although the academic literature about the gig economy has grown in the last years, its impacts on micro, macro, and meso levels must be better understood (Hofer et al., 2021). By adopting an expanded view of career paths, we argue that platform labor has to be analyzed together with 
circumstantial issues such as economic crises or high unemployment rates, surpassing the common knowledge that understands app-drivers as workers in a temporary condition while searching for an employment contract. Therefore, analyzing platform labor based on the workforce's heterogeneity allows exploring new possibilities regarding contemporary careers.

\section{METHODOLOGICAL PATH AND TYPOLOGY CONSTRUCTION}

The research context: The three reasons to choose Brazil as the locus of the empirical research were, first, the fact that the gig economy - a worldwide phenomenon - has found fertile ground to expand in the country. Because they require relatively accessible means of work (especially when compared to the formal labor market), gig economy activities such as ride-hailing apps stand out regarding their impact on the rates of occupation (Instituto de Pesquisa Econômica Aplicada [Ipea], 2019). Second, the Brazilian labor market shows a history of high informality rates and a formal sector offering poor working conditions. In addition, data from the Brazilian Institute of Geography and Statistics - IBGE (Instituto Brasileiro de Geografia e Estatística [IBGE], 2018) demonstrate that a substantial part of the workforce has a low level of education. According to IBGE, only $19.7 \%$ of Brazilian citizens aged 25 to 34 have completed higher education (the OECD average is $36.7 \%)$. The percentage of those who have no formal education or only have incomplete elementary education is high: $53.3 \%$ among the age group of $55-64$ years old, $44 \%$ in the $45-54$ age group, $32 \%$ in the $35-44$ age group, and $18.2 \%$ in the age group of $25-34$ years old. These figures can be used to analyze push and pull forces (Tran et al., 2019) concerning the gig economy. Third, as Briscoe et al. (2018) point out, it is important to expand the understanding of careers' aspects beyond the WEIRD countries, that is, the "western, educated, industrialized, rich, and democratic" nations (Briscoe et al., 2018, p. 119).

Methodological procedures: This is a qualitative study based on interviews conducted with 57 out of 58 app-based drivers approached. They were interviewed at their workplaces, in the southern Brazilian city of Porto Alegre, in the state of Rio Grande do Sul. The drivers were randomly selected and interviewed between December 2017 and December 2019 during rides requested by one of the researchers through three different platforms operating in Brazil. The definition of the number of participants followed the criteria by Saunders and Townsend (2016). For the authors, the number of respondents "is contingent on the broad characteristics of the population from which participants are chosen" (Saunders \& Townsend, 2016, p. 849) and can vary between 15-60 interviewed participants, considering their characteristics of homogeneity or heterogeneity. Thus, considering the Brazilian characteristics, the purpose, the research question guiding this study, and the time elapsed between the beginning and end (two years) of data collection, we understand that the number of participants is adequate. The interviews followed a semi-structured script focused on understanding the drivers' motivations to enter the activity, their future work prospects, professional history, and education level. One of the drivers approached had a hearing impairment, and this interview was disregarded since it could not be carried out appropriately during the ride in the same way as the others in the sample. All the answers were recorded and transcribed, and the names of the drivers were deleted to ensure anonymity.

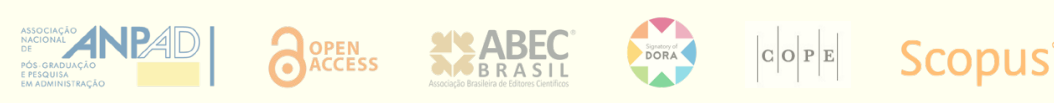


Categorization process: After a pre-analysis of the material, the answers were organized in an electronic spreadsheet. In a first analysis, the interviews were categorized according to the drivers' status either as full-time drivers (whose income depends solely on the activity - 45 drivers) or part-time drivers (whose earnings are supplemental income -12 participants). Afterward, the responses were analyzed by identifying reference points from career theoretical perspectives related to agency, time, and context.

As for the 'time' perspective, we adopted the notion of Gunz and Mayrhofer (2015), choosing one of the possible dimensions for time. Therefore, the time category was renamed 'permanency,' reflecting the worker's intention to continue the activity or to stop it in the future (whether soon or not). Its variations are 'temporary,' which means that the driver manifested the intention to stop the activity and (re)start doing something else, or 'permanent,' which means that the participant has expressed their intention to continue working as an app-based driver.

Among the many possible elements for the 'context' perspective, we considered the interviewee's education level, which is a key indicator for the labor market, especially in segmented areas, and is considered a global priority in the Sustainable Development Goals (SDGs) agenda (ILO, 2015). It is widely recognized as an essential variable of social mobility and working conditions (Schultz, 1961) since highly educated workers are better positioned to negotiate terms of employment (including types of contracts and working time arrangements) (ILO, 2015). Thus, education is important at micro and macro levels, contributing to increasing countries' productivity and competitiveness (ILO, 2018b; 2018c). In this sense, the individuals' education level is identified by the space where they experience their career (Mayrhofer et al., 2007) and by their participation in the legal, political, educational, and socioeconomic status of a country (Briscoe et al., 2018; Reiss et al., 2020). The context category, considering this theoretical-analytical view, was then named 'education level,' sorting the workers according to the years of formal study (skills development) in variations of 'high' (which means at least undergraduate level in progress or completed) and 'low' (technical certificate to no formal education at all).

This categorization gave rise to four primary types of drivers: highly educated and poorly educated temporary workers; and highly educated and poorly educated permanent workers. These categories were summarized in Table 1, creating four main categories of drivers. All drivers were classified under types labeled from A to D (for full-time drivers) and from A' to D' (for part-time drivers).

Table 1.

General typology of Brazilian app-based drivers

\begin{tabular}{llll}
\hline & \multicolumn{2}{l}{ Education level } & \\
\cline { 2 - 3 } & & Highly educated & Poorly educated \\
\hline Permanency & Temporary & Types $A$ and $A^{\prime}$ & Types $B$ and $B^{\prime}$ \\
& & Temporary and highly educated & Temporary and lowly educated \\
& Permanent & Types $D$ and $D^{\prime}$ & Types $C$ and $C^{\prime}$ \\
& & Permanent highly educated & Permanent and poorly educated \\
\hline
\end{tabular}
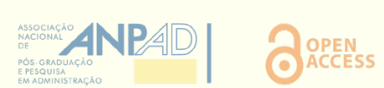
Analysis process: In light of this typology, the material was analyzed again, and each participant was placed in one of the eight possibilities (A, B, C, or D, for full-time workers; or A', B', C', or D', for part-time worker). Then, we developed a map that crosses the dimensions of permanency and education level. They were understood in this study as a continuum and not as absolute and rigid categories, and all the 57 interviewees were positioned on the map, considering the eight possibilities as quadrants (Figure 1).

In Figure 1, the horizontal axis of the map indicates the condition of permanency. It varies in a continuum from permanent to temporary: the more to the left, the stronger the driver's expressed intention to continue permanently in the activity; the more to the right, the stronger the intention to stop the activity. The vertical axis indicates the drivers' education level, in a continuum that varies from highly educated (which means at least undergraduate level, in progress or completed, in the upper quadrant) to poorly educated (technical certificate to no formal education, in the lower quadrant).

The larger area of the map graphically represents the situation of the 45 drivers who work fulltime. The smaller area, in the center, shows the 12 drivers who work part-time (quadrants A', B', C', and D'). Male drivers are represented in blue and female drivers in red. After the allocation of drivers in their respective quadrants and proceeding with the qualitative analysis, the groups received a name that describes their features. The next sections describe and analyze the typology.

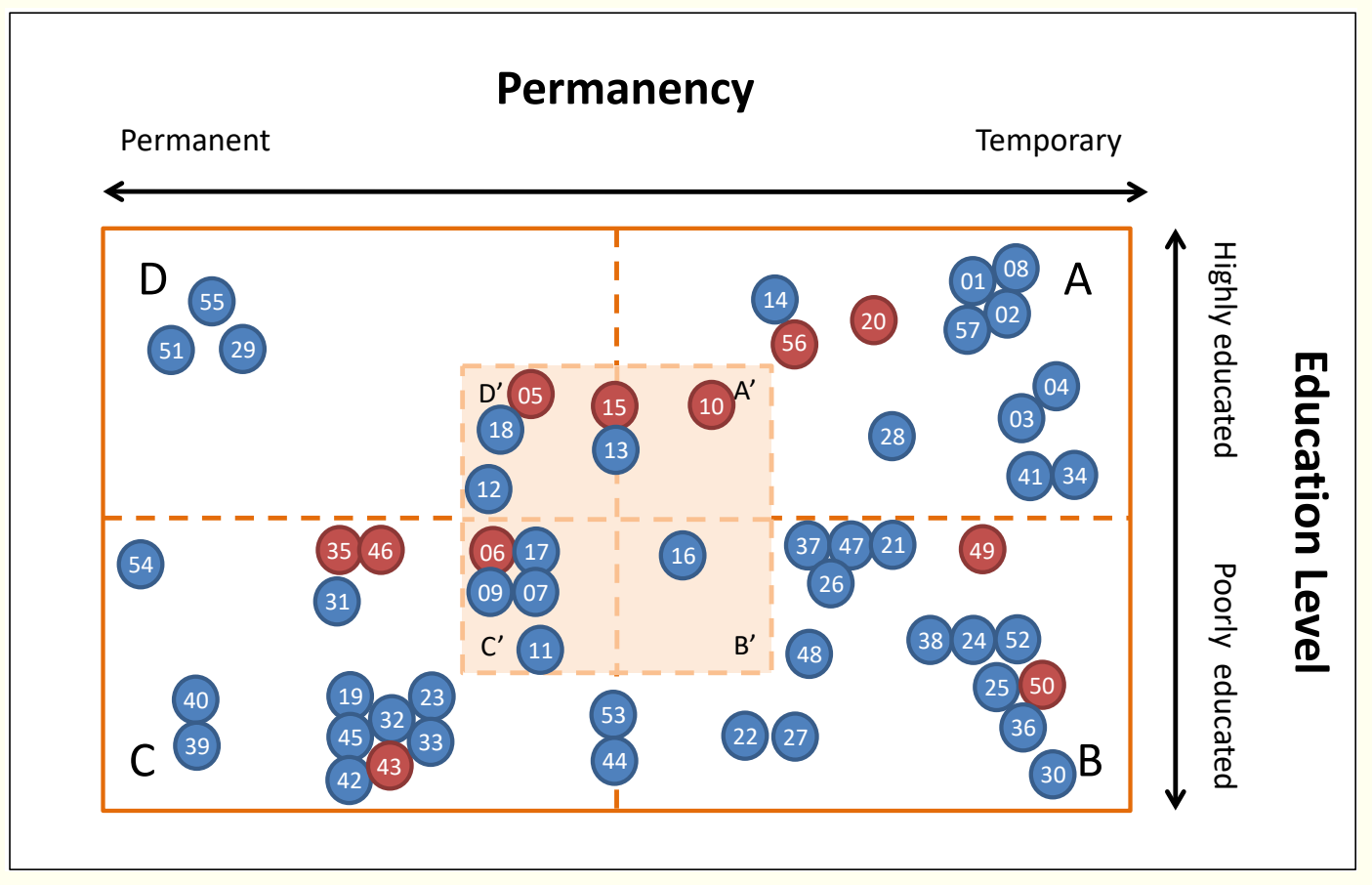

Figure 1. Overall representation of Brazilian Uber drivers interviewed.

\section{PRESENTATION OF MAIN RESULTS}

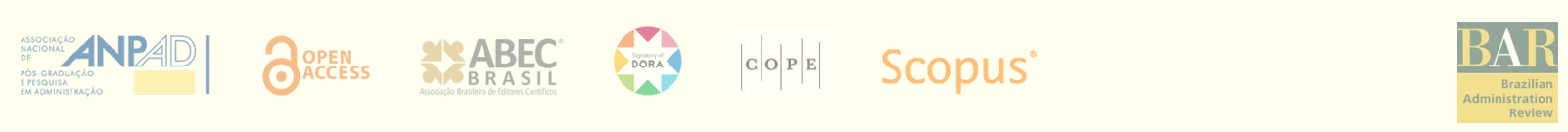


Although this is a qualitative study, it is worth mentioning some quantitative data about the interviewees. There is a predominance of full-time drivers (45) compared to part-time workers (12). The majority of drivers are male (46), which may be explained, historically, by a characteristic of the sexual division of labor, where driving activity has been primarily male.

Figure 2 summarizes the data for the study's main categories - permanency and education level. There is a predominance of poorly educated people working in the activity, with 36 drivers versus 21 highly educated professionals. Regarding the intention to stay (permanency), the results are similar. The majority want to abandon the activity: 29 drivers expressed their intention to stop the app-based driving activity versus 24 that expressed their intention to stay. As shown in Figures 1 and 2, four drivers were placed on the line between quadrants because it was not possible to identify in their speeches an expressed intention to continue or to stop the activity.

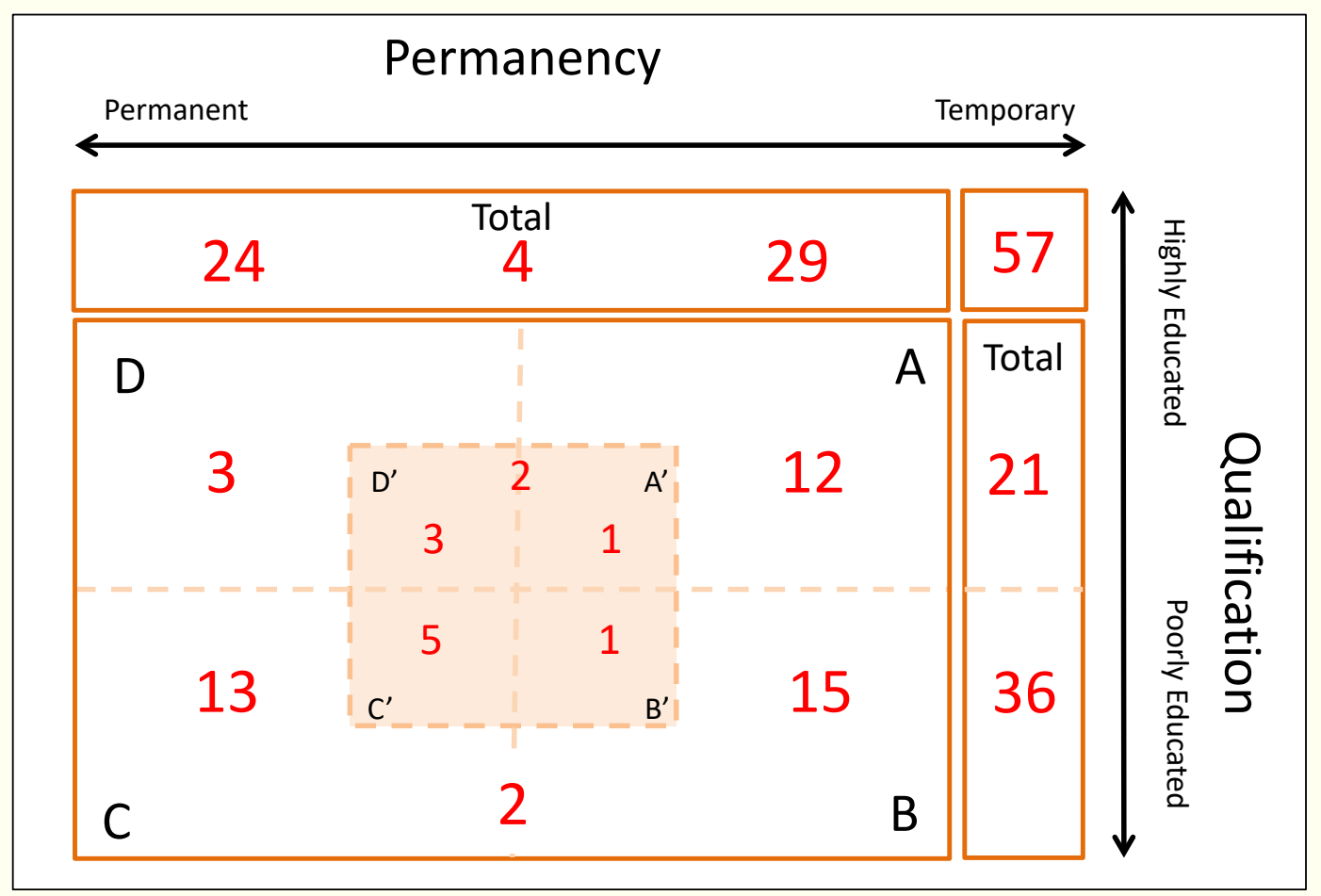

Figure 2. Quantitative summary of drivers by category — permanency and education level.

Although drivers of the same type share the same main characteristics, there are several different profiles, even within a single quadrant. These profiles are presented below.

\section{Full-time drivers}

Type A - The 'In Between' Planner. This category gathered the highly educated drivers who stated their intention to stop the activity at some point, even though this was currently their primary source of income. This quadrant represents those who were in an intermediate situation; that is, they were working as drivers while looking for or trying to start another paid activity. The

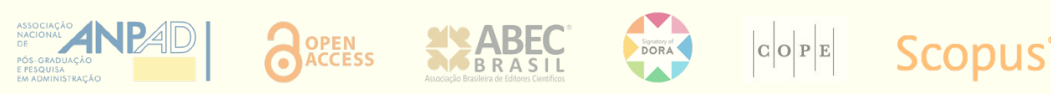


interviewees placed in the upper half of quadrant A (Figure 1) had a degree, whereas those in the lower half were undergraduate students. The closer to the upper right corner, the greater the capacity to develop concrete plans that reinforce the condition of temporary drivers (as in the case of drivers $1,2,8$, and 57 ). The closer to the center, the less capacity to fulfill their expressed desire to stop the activity (as was the case of drivers 14, 20, and 56). Drivers 4, 3, 28, 34, and 41 hoped to migrate to the careers they were studying for once they obtain their university degrees. Driver 34 was close to retiring; he worked as a driver to have an income, in addition to continuing to contribute to social security.

The two women of type A were lawyers. One of them, driver 56, reported that she was disappointed in the field of Law, but still intended to look for another area to work. She had a partnership with her father,

“... which was not actually a partnership. Then I left the business in May! It was awful... awful, awful. Then I left, and I support myself working for Uber. I was like a slave in there, and now I find myself like a slave in here... [laughs]".

Driver 8 was Italian and was in Brazil to implement a project for a German company. Because the project had not started, he worked as a driver while he was waiting. Driver 4 was a professor of Journalism who was laid off and had worked with the ride hailing apps while he was looking for a job. Three respondents (numbers 1, 2, and 57) were temporarily working as drivers while planning to move to another country.

It was noted that type A drivers have adapted to activities significantly different from their original careers. For them, working as an app-based driver was a momentary alternative to 1) remain economically active during a period of economic crisis, with expectations of resuming their occupations; or 2) carry out a life project - such as living abroad, starting a business, retiring, or finishing school.

Type B - The Good Unemployed. Type B workers were the most numerous group (15 drivers out of 57 respondents). Drivers in this quadrant held technical certificates or achieved an education level below higher education. The lower right corner includes drivers with strong intentions to migrate to other activities, who expressed a desire to return to the traditional job market or to start their own business - although none of them had objective plans for this (as is the case of drivers $24,25,30,36,38,49,50$, and 52). Drivers 22 and 27 were professional drivers who expressed intentions to return to their original activity (bus and truck driving). The paths of the two women in the group, 49 and 50, are marked by many adjustments, including formal, informal, and entrepreneurial activities, having experienced various occupations throughout their lives. Among the men, several reported the long and exhausting work schedules of the appbased driver activity. However, they continued working as drivers considering the activity's benefits outweigh the negative aspects of their previous activity.

Ten out of fifteen drivers entered this activity after losing their jobs. Out of the five that were not laid off, drivers 50 and 52 decided to leave their micro-businesses. Driver 49, one of the two

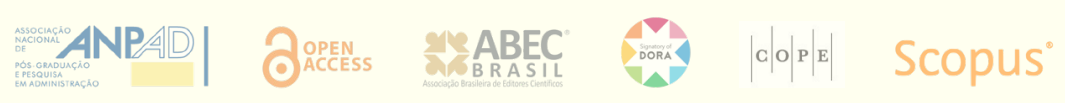


women in type $\mathrm{B}$, decided to return to the job market after many years of raising a disabled son who passed away. Drivers 47 and 48 had resigned from their jobs. Driver 47 said:

"I need to take care of myself. I have a family, I have children, and was getting sick working there, psychologically."

These workers represent the category of "good unemployed" (Guimarães, 2012, p. 124). They are individuals used to adopting socially expected behavior - in this case, to avoid being without work, regardless of the adverse conditions. They were using the new gig economy ways and mechanisms to find work and support themselves as active workers during the financial crisis. For this group, the driving occupation can be the link between employment and unemployment. Some of them defended the temporality of the occupation as a driver, considering the bad moment of the formal job market, which demands a lot and pays very little.

Although they were, in general, more vulnerable due to a lower education level, most of the type B drivers recognized the difficulties and problems of the activity and therefore wanted to stop it. However, most of them did not have a defined occupation and continuously needed to adapt to the opportunities, often changing activities or sectors in a permanent search for jobs that offer better conditions, whether in an organizational career or through the dream of having their own small businesses. This profile reflects the characteristics of the protean 'logic': the desire to decide, of their own will, to change positions in the labor market, even in quite adverse conditions.

Type $\mathrm{C}-$ The Dependent. The interviewees in this type were poorly educated workers who report explicit intentions to be app-based drivers permanently. Most of those who fit into this category (nine out of thirteen) were already professional drivers when they migrated to app-based activity - such as drivers 39 and 40, who were taxi drivers, and drivers 19, 23, 32, 33, 42, 43, and 45, who were bus or truck drivers. Many mentioned the low wages paid to drivers in the formal labor market.

Two out of the three women in the group, 35 and 46, pointed out that the driving activity is more advantageous when compared to the professional reality they had in the past. They worked in formal occupations in administrative jobs and reported they now make more money and have more time for their families than before. Therefore, they do not intend to return to the formal labor market. This fact is associated with a "compulsory inactivity," as explained by Fraga and Rocha-de-Oliveira (2020, p. 766), when referring to the barriers women face in the labor market, which leads to professional stagnation. Career mobility is not fully available for these women, especially when considering their social and geographical context. For driver 35,

\footnotetext{
"if you do not train, your salary is not very high... so, to be able to do something, you have to go for it. I was called back to work at the hotel, but I didn't want to. Here I earn the same thing but work only five hours a day."
} 
Drivers 44 and 53, who worked as an entrepreneur and a waiter, respectively, were placed in the boundaries of quadrants B and C (Figure 1) because they explicitly stated that they were 'giving it a try,' expressing no desire to continue or stop.

Type C represents, especially for those who were already professional drivers, adaptation to changes in the occupation: as their primary activity was already driving, they adapted to work in a different form. Group $\mathrm{C}$ is the one with fewer complaints regarding the app-based driver routine, and, in general, the interviewees mentioned working in better conditions now than in the past. In this group, the individuals made clear they do not desire to re-enter the formal market in the future, mainly because the jobs offered are not very attractive for them considering their low education level.

Type D - The Freedom Seeker. These drivers were highly educated and expressed intentions to continue working permanently as app-based drivers. They reported seeing advantages in the current occupation when compared to previous activities. It was the least numerous profile, with only three cases.

Driver 55 held a university degree and used to own a gym. With an entrepreneurial profile, he reported that he transformed driving into an entrepreneurial activity. He used part of his income to buy more cars and rent them to other drivers. He started with one car and already had three vehicles, two of them currently rented. Driver 29 considered this activity 'the best in the world' when compared to the stress, pressure, and lack of flexibility he had in his job at a multinational company. Driver 51 revealed that he no longer saw himself as an employee in a position in the traditional labor market:

"after you experience flexibility, it's hard to go back."

He declared to have left his business because he lost the joy of being an entrepreneur:

"being an entrepreneur, having a store... it is no longer for me."

Group D represents a wide adaptation to a new work context: professionals who migrate from occupations that require high education levels - but less favored in terms of perceived benefits (in their view) - to opportunities with different configurations and a lower degree of formalization.

\section{Part-time drivers}

Type A' - The Flexible. Type A' drivers worked temporarily in the activity on a part-time basis, and this was not their primary source of income. Driver 10, the only representative of this category, had a very different trajectory. She graduated in international trade and worked in the area, but she did not want to return to that industry. She spent many years working on cruise ships, an activity that allowed her to visit different places. She returned to Brazil because of family pressure, but she planned to return to work on ships. She worked as a driver in her free time, alternating this activity with a waitress job while saving money to leave the country again. High

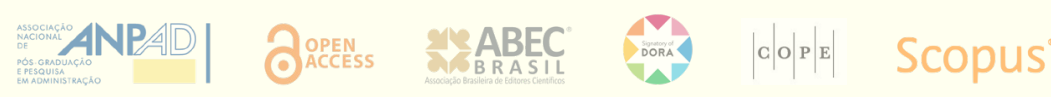


flexibility to switch careers was a remarkable characteristic of driver 10 . The development of daily strategies regarding the career allowed an effective intervention in such a journey, which was permeated by changes and (im)possibilities.

Type B' - The Poor Entrepreneur. Driver 16, the only representative of this category, reflected the type B profile mentioned above, especially when it comes to poor education and the desire to stop driving in the long run. He was an entrepreneur that worked as a driver to supplement the family income and expressed the desire to abandon this activity and modify his business. However, the interviewee did not demonstrate to have objective plans to materialize these desires. The workers in this quadrant, in general, have a strong desire, combined with need, to keep trying and doing what seems possible to them with what they have to offer to the market.

Type C' - The Semi-dependent. This category gathered drivers who worked to supplement their income and intended to continue to do so. Out of the five drivers placed in type C', three were retired $(6,7$, and 9). They revealed to be unable to 'be idle' and were reluctant to accept retirement and leave the labor market. Driver 7, a truck and bus driver, also revealed that he needed social contact: every day, he used to meet other drivers for coffee in the middle of the morning. He also highlighted the low wages paid to workers in this occupation in the formal market:

"Is it worth working for R \$ 1,500 per month? I don't think so!"

For driver 9, the low retirement salary did not provide him with the lifestyle he had before, with family gatherings and barbecues. Hence, the working schedule of a few hours a day and weekends off serves his purpose.

Interviewees 11 and 17 were, respectively, a private investigator and a musician - activities marked by informality in Brazil. Accustomed to irregular demands in their original occupations, they were working as app-based drivers while in between jobs to make a living since their original occupations presented a sharp drop in demand during the economic crisis. The speech of driver 11 was emblematic:

“The bills don't stop arriving, you know ... it's like the tide on the beach.”

Type D' - The Enjoyer. In this quadrant, three highly educated workers who drove part-time were observed. Driver 18 considered himself too young to stop (he is retired under special provisions):

"I am super young ... I can't be idle. I like to work! I like to work! Since I retired, I've been working for Uber. I just bought myself this car! I bought it this week. It was a Christmas present I gave myself."

Driver 5, a pensioner receiving a sickness benefit, reported the difficulties she had when she worked for a multinational company in a management position. She explained why she decided to drive: 
"It's complicated... I worked 13 hours a day, sometimes more. Sometimes I wasn't on duty, and the president would call me late at night. It was crazy! With two small children. This situation went on until I was hospitalized in 2013 when they discovered a chronic disease. So, in 2016 I was fired, and since then, I've been getting financial support from social security. The thing is that you receive the money in a month but nothing in the next one, and you have this issue of not knowing what will happen tomorrow, you know what I mean? With two kids... So I decided to be a driver for Uber. I don't think that there's anything demeaning about it."

Driver 12, a veterinarian disenchanted with the more 'traditional' vet career, took on the gig economy professional lifestyle, working as a dog trainer and dog walker and as an app-based driver on rainy days:

"on rainy days, it is impossible to walk dogs, so... to make some money, I drive. In the past, I used to give myself time off, I used to stay at home playing video games, but nowadays, it's not good to be caught off guard. It is good to have some money to spare."

Two drivers were classified between quadrants A' and D', since they did not express their desire to stop or continue the activity. The statements reveal a profile quite different from that of the other workers interviewed, who work out of necessity. Driver 15 was a young man who worked as a temporary military officer in the army and as a driver to save money. He says:

"I like having money saved, you know, I don't like spending it all, I like having an emergency reserve. I started on Uber, I started saving money, and I even managed to buy this car."

Driver 13 reported:

"I get my money here. I'm a psychologist, I have a Psychology degree, but then I had twins, 20 years ago, and I stopped everything, I became a mother... and after the girls went to the university... I said, oh, I have nothing to do! [laughs] I have the car insurance to pay, so I'm going to work to pay for my car insurance. I want to buy some gorgeous cooking pots... but they are expensive! [laughs] Those ceramic cooking pots, you know? Well, so I will finish paying my insurance, and Cabify will give me my pots [laughs]."

In summary, types A (The 'In Between' Planner and The Flexible) and B (The Good Unemployed and The Poor Entrepreneur) represent a temporary adaptation to the activity since they do not intend to continue driving. However, group A members deal with the changes in context that arose (partly due to the long duration of the country's economic crisis and partly due to new life projects) by creating more or less objective and elaborated plans. Thus, they aim to achieve a future that brings them better working conditions. On the other hand, type B represents a worker profile accustomed to constant adaptations to different informal activities, as their low qualifications leave them more exposed to changes in the labor market, whether economic or technological. Group B workers' path goes back and forth between informality, entrepreneurship, and the organizational career, developing a high adaptive capacity (Briscoe \& Hall, 2006) resulting from changes in the context. These workers represent a group of typical workers from countries with high informality rates: a worker with low decision-making ability and with imposed adaptation - the dark side of the career field, a profile that is still little explored within the protean career (Baruch \& Vardi, 2016).

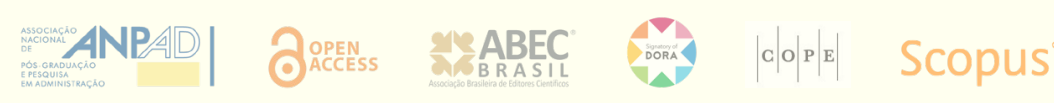


The groups C (The Dependent and The Semi-dependent), in which there is a transformation from the old occupation as a driver, and D (The Freedom Seeker and The Enjoyer), where one identifies a new career opportunity, on the other hand, represent more permanent adaptations. They are linked to the development of new individual skills and self-direction of individuals and have different forms of protean capacity (Briscoe et al., 2006; Hall, 2004). Figure 3 summarizes all the driver types and represents the final typology.

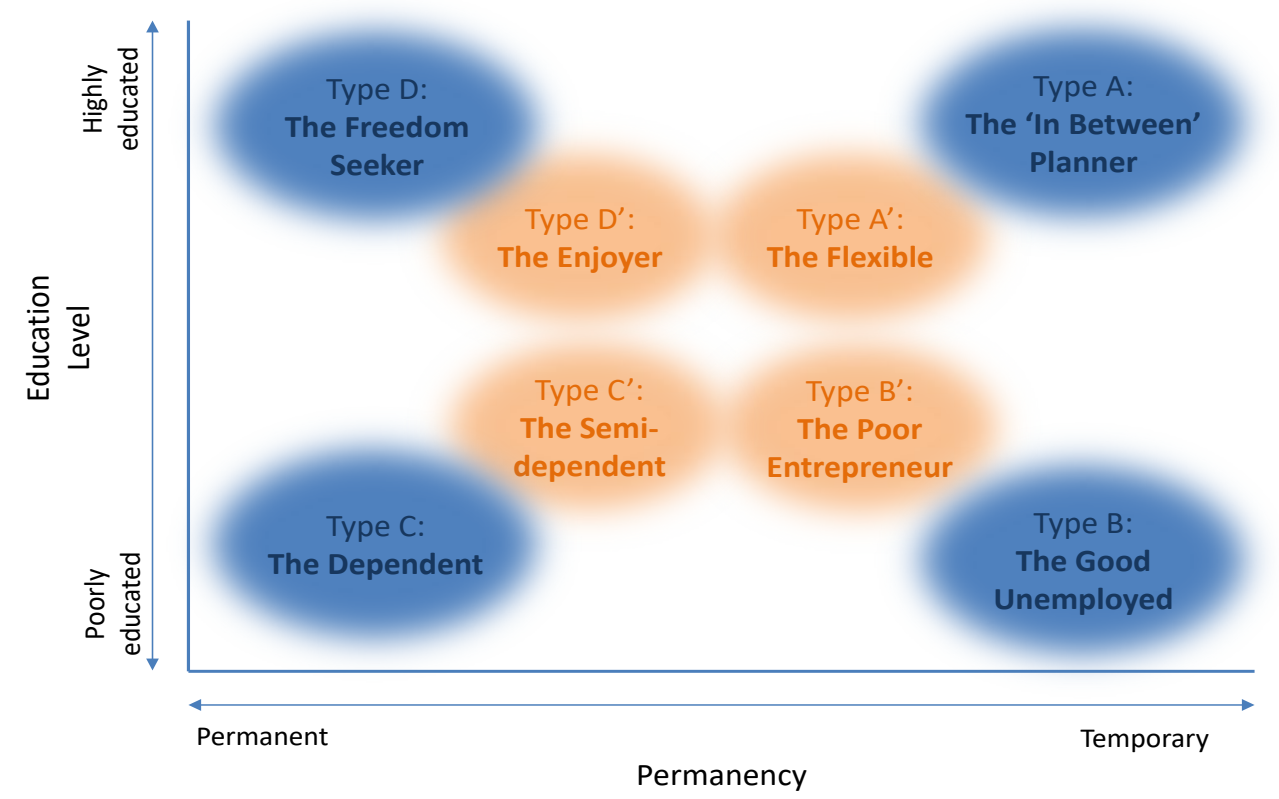

Figure 3. Typology of Brazilian app-based drivers.

\section{DISCUSSION: WHAT DO THE DATA TELL US?}

Careers are closely linked to the particularities of the labor markets where they operate (Mayrhofer et al., 2007). Especially in developing countries, historical issues and contextual characteristics leave their marks on most occupations and career trajectories, where usually there are significant heterogeneities and inequalities (Valente, Patrus, \& Guimarães, 2019; Wood, Lehdonvirta, \& Graham, 2018). On the other hand, the gig economy is a global phenomenon that is transforming and restructuring labor markets all over the world. Studies carried out in developing countries where ride hailing is becoming an important labor market reinforce the need to broaden the understanding of the gig economy's growing phenomenon. Reilly and Lozano-Paredes (2019) investigate the Colombian context, where informality exceeds $48 \%$ in Cali. Kashyap and Bhatia (2018) point out the segment's growth for companies like Ola and Uber in Delhi, in India, highlighting the poor working conditions of a labor market as a backdrop that reveals traits of great precariousness and vulnerability. Malik and Wahaj (2019) investigate the very particular context of Pakistan and point out that ride-hailing companies like Uber are

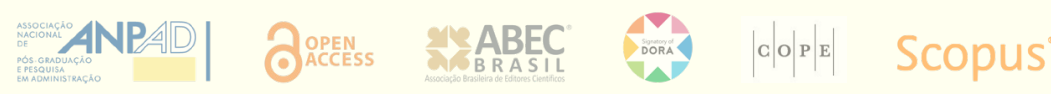


contributing to women empowerment as well as a culture of trust and family confidence. By applying a micro-macro level analysis through the career and labor market lenses, the analysis of the Brazilian case can help widely understand the phenomenon - especially considering that it is one of the world's largest ride-hailing markets and have a career ecosystem that has been built throughout the country's history and merges with the new occupations that arise.

The analysis of the data allowed us to develop an empirically grounded typology by mapping four driver types (type A: The 'In Between' Planner; type B: The Good Unemployed; type C: The Dependent; and type D: The Freedom Seeker) and four subtypes (type A': The Flexible; type B': The Poor Entrepreneur; type C': The Semi-dependent; and type D': The Enjoyer). It was possible to cross three dimensions that mark individual careers: in addition to the agency, a basic critical notion of the contemporary careers views, like the protean career theory, two additional dimensions were also analyzed: context, characterized by levels of qualification, social status of the profession, and development of drivers' skills; and time, which is characterized in this study by the intention to continue or stop the activity.

On the agency side, the app drivers' typology shows the existence of very heterogeneous profiles, which are linked to the structure of the Brazilian labor market and show different ways of adaptation. As every driver is personally dealing with different situations - such as unemployment, aging, retirement, or gender issues, they use their agency capacity to adapt to this new professional condition. Their personal history is closely connected to the forces that push or pull (Baruch, 2015) them to the activity. In this scenario, the worker's adaptability, highlighted as a fundamental attribute of the protean career, takes on a different meaning (Baruch \& Vardi, 2016), distant from the organizational space and linked to informality. Most workers need to adapt (and they are used to doing so) to economic or technological changes that periodically reconfigure their work. The adaptability is a mark of the career trajectory of several interviewees - for example, the mentioned entrepreneurial activities that expose a sort of subsistence entrepreneurism. These activities reveal those subjects' search for alternatives, in general, informally, by taking advantage of the gaps in the economic environment that allow them to meet their needs, considering the many difficulties they face when looking for placement. Given they are under unstable and discontinued employment regimes, they see the possibility of survival in the next venture.

The boundaries of the context, therefore, limit individual action. Since careers are both individual and collective (Gunz \& Mayrhofer, 2018), the historical elements (in this empirical case dating back to the Brazilian transition from an agricultural to an urban society) have echoed in the development of the careers ecosystem of Brazilian workers and the contemporary gig economy activities. They portray and represent the phenomenon known as the Brazilian "way of life" ("jeitinho", in Portuguese), a sort of 'instrument' through which most of the informal and semi-formal relationships are developed in Brazil (Nogueira \& Zucoloto, 2017, p. 268).

Therefore, it is not possible to carry out analyses on the Brazilian career ecosystem that disregard the educational factor. Education level becomes a preponderant factor for most interviewees (36 drivers) who have no technical degree or higher education. From this perspective, it is not

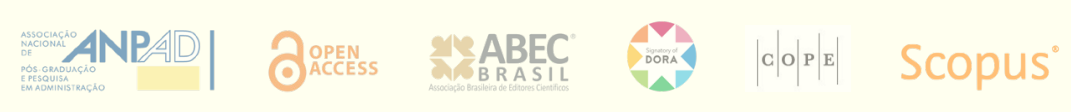


surprising that the number of interviewees with low education level who intended to continue the activity ( 13 workers) was very similar to those who intended to stop it (15 workers). In the highest educated stratum, there was a significant difference between those who wished to continue and those who wanted to stop the activity (three versus twelve drivers). In this perspective, education is an element decisive not only for the drivers' permanence in the activity but also for their performance while working. The lower the education level, the greater the dependence, mainly financial, which can affect the desired output. On the other hand, activities related to the gig economy have a strong appeal to micro-entrepreneurship and present themselves as job opportunities - temporary or not - mostly due to them being easy to access. To act professionally as an app-based driver reveals a precondition that favors starting and continuing the activity: for many interviewees used to poor working conditions, being a driver is not much worse than what they used to do in other jobs. Evidence of this situation is the similar number of interviewees who seek to stop the activity (29) and those who wish to continue driving (24 respondents). Considering that it is a job that admittedly has poor working conditions and low pay, it was to be expected that few would want to continue driving for a long time.

As for time, it is interesting to analyze that the majority of drivers consider themselves to be living a temporary experience. The types A, A', B, and B' (the 'In-Between' Planner, the Flexible, the Good Unemployed, and the Poor Entrepreneur), and also the four drivers who were placed at the boundaries of quadrants, seem to be in a liminality state (Bamber et al., 2017; Borg \& Söderlund, 2015). As Ibarra and Obodaru (2016) point out, it seems to be a sign of contemporary landscape that a growing number of people are professionally experiencing a feeling of suspension "between insider and outsider roles and projects or gigs" (Ibarra \& Obodaru, 2016, p. 2). Liminality is an anthropological concept for a transitory state of being betwixt and between, neither here nor there, neither one thing nor another, in between roles and/or identities (Bamber et al., 2017; Ibarra and Obodaru, 2016). While types A and A' seem to be in a transitional liminality state, types B and B' showed they could be in a permanent betweenness state or in permanent liminality (Bamber et al., 2017). If Ibarra and Obodary question "whether being 'protean' is a state or a trait" (Ibarra \& Obodary, 2016, p. 14), Gunz and Mayrhofer (2015) alert us that the temporal perspective is linked to the dimensions of context (space) and the actors' individualities.

The typology presented in this study shows different ways of experiencing the activity and the career redirection in the same career ecosystem. Such redirection reveals, for many workers, a self-managing individual who has been making unplanned, sinuous, and precarious movements toward the next occupation. In this sense, gig economy activities, mostly because they are easy to access, are compatible with the need to find means of subsistence. The activity of app-based drivers (and, it seems, also of other activities of the platform economy that attract this worker profile) presents a new format for historical structural problems of the Brazilian career ecosystem. Thus, in countries with high informality rates, platform labor leads to a different level of discussion, which is not merely circumstantial or caused by economic crises, or even related to high unemployment rates. In these countries, platform labor represents a new stage in adapting different informal workers' profiles to this technological change.

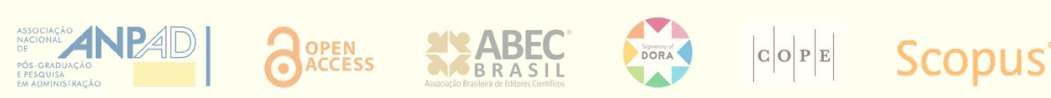


The contemporary view of careers recognizes the dynamism of the environment and the individuals' leading role as the owners of their professional lives. Employability, freedom, and flexibility are keywords to the new psychological contracts made between workers, organizations, and societies (Baruch, 2015). The rhetoric of choice (Vinkenburg, Van Engen, \& Peters, 2015) of the basic protean notions - self-direction and values orientation (Briscoe, Hall, \& DeMuth, 2006) - is focused on attitude, based on well-defined objectives and on achieving success in the career path. Thus, a protean individual must have the combination of these two elements to a high degree, with the full achievement of both metacompetencies (Hall, 2004); otherwise, they will be dependent, rigid, or reactive (Briscoe \& Hall, 2006). Thus, stigmas are created allocating certain strata of workers in subcategories. However, this is a narrow view that frequently ignores the push and pull factors between the environment and the workers' agency (Baruch, 2015). Understanding the factors and conditions that circumscribe the new work arrangements, such as self-employment, is a challenge to career theories (Tran et al., 2019).

\section{CONTRIBUTIONS AND FUTURE RESEARCH DIRECTIONS}

This study brings some theoretical and practical contributions through the development of the typologies presented above. First, many contemporary career theories emphasize the individual perspective, especially concerning the agency capacity. Baruch and Vardi (2016) have pointed out that there is a kind of 'glorification' in the current theoretical framework on careers. The exclusive view on the bright side of career theories tends to ignore the complex and multifaceted experiences developed under unpredictable and uncertain circumstances that cross the professional paths. The analysis of multiple trajectories in a career ecosystem helps stress the factors that are usually underestimated in career theories but have shown to be very important for the workers' path. The analysis of how time and context influence career trajectories (Briscoe et al., 2018; Gunz \& Mayrhofer, 2018) in a developing country - and in scenarios of great inequality, such as in Brazil - opens new spaces for reflections and future research. As demonstrated in this study, the conception focused on the individual agency (present not only in the protean but also in several other perspectives) lacks essential elements. Career theorists should start to consider how time and context influence the workers' careers to adopt broad views on the understanding of professional paths. The heterogeneity that makes up the mass of workers involved in the activity reveals its different aspects and reinforces the need to observe the phenomenon from macro and micro perspectives.

Second, this study helps deepen the understanding of the gig economy phenomenon and its consequences for the world of work. It is consensual that new ways of economic and labor organization impose reconfigurations of labor relations. To deal with the new configurations of flexibility is necessary to move forward in analyzing contemporary labor relations, which are no longer characterized only by traditional contracts. The gig economy phenomenon has raised concerns in different spheres, inside and outside academia, due to the intensification of the labor relations' flexibilization and its effects on working conditions.

Third, by analyzing the heterogeneity of Brazilian app-based drivers' career ecosystem, it was possible to note different ways to adapt and change career plans. Workers are faced with the

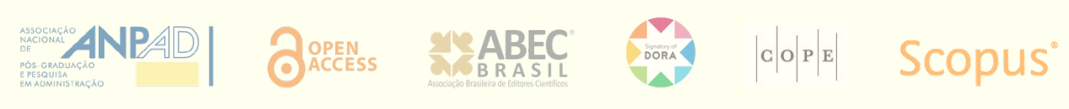


inefficiencies of traditional markets and the countless possibilities that open up with the development of new technologies. Workers with the most diverse skills and knowledge are either pushed into the gig economy by the immediate need for subsistence or attracted by the positivity contained in the notion of freedom and flexibility at work. In this sense, the idea of living work as an experience is combined with new ways of thinking and living that are part of the social space in which everyone is inserted. It is also worth mentioning the existence of several responses, spread across all types, which evidence a kind of 'disenchantment' - both with the formal labor market and traditional entrepreneurial activities, revealing the desire for a self-directed change toward new careers. Thus, the economic and technological context in which the gig economy develops appears to many as an opportunity (illusory or not) to design a path that will distance them from this discomfort.

These theoretical contributions have opened space for future research that could help us understand a movement we call 'gig career,' exploring individual trajectories and the career ecosystem's historical and contextual characteristics. It is crucial to understand the contexts in which gig careers emerge and develop, in all their heterogeneity and complexity. In line with the literature reviewed, this study reinforces that the gig economy is a phenomenon spatially and temporally situated. Its analysis needs to consider several factors under the risk of falling into dichotomous analyses that do not reach the depth of the already identified transformations.

This study also brings some practical and managerial implications for the fields of administration and human resources management. One of the striking characteristics of the gig economy is the widespread understanding of the workers' autonomous character, which is a conception with important repercussions on working conditions, collective representativeness, and social and legal protection (Berg, Furrer, Harmon, Rani, \& Silberman, 2018; Johnston \& Land-Kazlauskas, 2018). Turbulent contexts in a hyperconnected society have demanded from the platforms a more socially responsible performance. The answer, however, does not always follow the demands in their most immediate needs (Fairwork, 2020). Work management based on immediate rewards has direct implications for the worker's mental and physical health. Gamification and algorithmic management (Bucher et al., 2021; Walker et al., 2021) as a labor-management method can lead to addiction and compulsion to work, where long hours and physical exhaustion are frequent. These characteristics impact the driver's productivity - and this can be seen throughout the eight different types of drivers found. It results from a labor-management process that relies on how well the worker manages the app-based activity. Such analysis may also be related to the contextual element under investigation in this study, that is, the level of education of workers, as highlighted above. The education level emerges as an essential element of adaptation strategies, showing that within the same activity, the career path - from admission to the construction of possibilities for migration to other stages - can take different forms. It is essential to mention that this activity essentially has an autonomous character. Even though this is not their original occupation in many cases, the workers do not receive training or orientation - neither for the management of work and billing nor for the personal control of their remuneration. The platform only operates to facilitate the meeting between supply and demand for rides, limiting themselves to acting in the imposition of rules that should also be part of the workers' know-how.

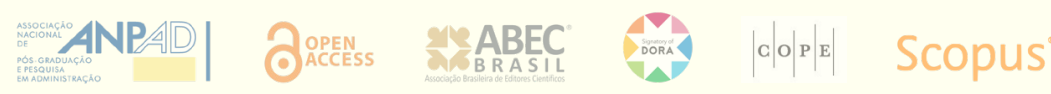




\section{FINAL CONSIDERATIONS}

The main objective of this research was to analyze how the perspectives of time and context, in addition to the individual's agency, influence the career paths of workers in a gig economy activity. Today, platform-mediated activities are increasingly present in a complex scenario that involves historical and contextual issues. They have been part of the reality of millions of Brazilian workers who see them as an alternative to make a living and to (re)enter the labor market. Against this backdrop, this study developed a typology of app-based drivers based on a qualitative analysis of 57 interviews with these workers.

We identified four types of full-time drivers (type A: The 'In Between' Planner; type B: The Good Unemployed; type C: The Dependent; and type D: The Freedom Seeker) and four types of parttime drivers (type A': The Flexible; type B': The Poor Entrepreneur; type C': The Semi-dependent; and type D': The Enjoyer). A mosaic of transformations was identified, understood as a set of different manifestations of the protean abilities due to the contextual and temporal barriers presented to each worker in the career ecosystem. This finding emphasizes the importance of deepening the analysis that crosses different contextual elements that affect career paths - among them, the gig economy, as a growing phenomenon, and the understanding of career environment in a developing country such as Brazil.

As research limitations, the interviews were conducted at the drivers' workplace and during working hours. In-depth interviews, which allow more time to delve into specific issues, are recommended. In addition, the expansion of the study to encompass other regions can contribute to unveil other realities and assist in the development of the typology. This research is limited to understanding the realities of app-based drivers, which reflect only a fraction of the universe currently called the gig economy. New studies covering other activities and involving the development of career paths in this context can be fruitful research for the future.

We believe that disjunctive associations between the individual agency and the macro context limit analysis of career development, maintenance, and transition. Therefore, it is clear that the dimensions of time and context have strongly influenced the drivers' career trajectory. The time and context elements act as forces that compete with or complete the individual agency. They also limit the area in which a person can work professionally and exercise their agency. These influences are not just momentary and circumstantial but also developed along with professional life and can be perceived at both the micro (individual) and macro (societal) levels.

\section{Funding}

This study was financed in part by the Coordenação de Aperfeiçoamento de Pessoal de Nível Superior - Brasil (CAPES) - Finance Code 001. 


\section{REFERENCES}

Arthur, M. B., Hall, D. T., \& Lawrence, B. S. (1989). Generating new directions in career theory: The case for a transdisciplinary approach. In M. B. Arthur, D. T. Hall, \& B. S. Lawrence (Eds.), Handbook of Career Theory (pp. 7-25). Cambridge, UK: Cambridge University Press.

Atkinson, J. (1988). Working conditions and small and medium sized enterprises. European Foundation for the Improvement of Living and Working Conditions. Luxembourg, UK: Official Publications of the European Communities.

Balaram, B., Warden, J., \& Wallace-Stephens, F. (2017). Good gigs: A fairer future for the UK's gig economy (Issue April). London, UK: RSA; Mangopay.

Balliester, T., \& Elsheikhi, A. (2018). The future of work: A literature review (No. 29). Genebra, SUI: ILO.

Bamber, M., Allen-Collinson, J., \& McCormack, J. (2017). Occupational limbo, transitional liminality and permanent liminality: New conceptual distinctions. Human Relations, 70(12), 1514-1537. https://doi.org/10.1177/0018726717706535

Baruch, Y. (2015). Organizational and labor markets as career ecosystem. In A. De Vos \& B. Van der Heijden, (Eds.), Handbook of Research on Sustainable Careers (pp. 164-180). Cheltenham: Edward Elgar.

Baruch, Y., \& Rousseau, D. M. (2019). Integrating psychological contracts and ecosystems in career studies and management. Academy of Management Annals, 13(1), 84-111. https://doi.org/10.5465/annals.2016.0103

Baruch, Y., \& Vardi, Y. (2016). A fresh look at the dark side of contemporary careers: Toward a realistic discourse. British Journal of Management, 27(2), 355-372. https://doi.org/10.1111/1467-8551.12107

Berg, J., Furrer, M., Harmon, E., Rani, U., \& Silberman, M. S. (2018). Digital labour platforms and the future of work. Geneva, SUI: ILO. $\quad$ Retrieved from https://www.ilo.org/global/publications/books/WCMS_645337/lang-en/index.htm

Borg, E., \& Söderlund, J. (2015). Liminality competence: An interpretative study of mobile project workers' conception of liminality at work. Management Learning, 46(3), 260-279. https://doi.org/10.1177/1350507613516247

Briscoe, J. P., Dickmann, M., Hall, T., Parry, E., Mayrhofer, W., \& Smale, A. (2018). Career success in different countries: Reflections on the 5C Project. In M. Dickmann, V. Suutari, \& O. Wurtz (Eds.), The Management of Global Careers (pp. 117-148). London, UK: Palgrave Macmillan. https://doi.org/10.1007/978-3-319-76529-7_5

Briscoe, J. P., \& Hall, D. T. (2006). The interplay of boundaryless and protean careers: Combinations and Implications. Journal of Vocational Behavior, 69(1), 4-18. https://doi.org/10.1016/j.jvb.2005.09.002

Briscoe, J. P., Hall, D. T., \& DeMuth, R. L. F. (2006). Protean and boundaryless careers: An empirical exploration. Journal of Vocational Behavior, 69(1), 30-47. https://doi.org/10.1016/j.jvb.2005.09.003

Bucher, E. L., Schou, P. K., \& Waldkirch, M. (2021). Pacifying the algorithm - Anticipatory compliance in the face of algorithmic management in the gig economy. Organization, 28(1), 44-67. https://doi.org/10.1177/1350508420961531

Codagnone, C., Abadie, F., \& Biagi, F. (2016). The future of work in the "Sharing Economy": Market efficiency and equitable opportunities or unfair precarisation? JRC Science for Policy Report, 1-100. https://doi.org/10.2791/431485

Codagnone, C., Biagi, F., \& Abadie, F. (2016). The passions and the interests: Unpacking the "Sharing Economy." JRC Science for Policy Report, 1-160. https://doi.org/10.2791/474555

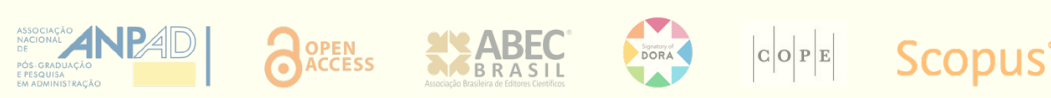


De-Stefano, V. (2017). The rise of the "just-in-time workforce": On-demand work, crowdwork and labour protection in the "gigeconomy” (Issue 71). Geneva, SUI: ILO. Retrieved from https://www.ilo.org/wcmsp5/groups/public/.. ed_protect/-mprotrav/-mtravail/documents/publication/wcms_443267.pdf

Degryse, C. (2016). Digitalisation of the economy and its impact on labour markets. ETUI. https://doi.org/10.2139/ssrn.2730550

Fairwork. (2020). The gig economy and Covid-19: looking ahead. Oxford, UK: Fairwork.

Fleming, P. (2017). The human capital hoax: Work, debt and insecurity in the era of uberization. Organization Studies, 38(5), 691-709. https://doi.org/10.1177/0170840616686129

Fraga, A. M., \& Rocha-de-Oliveira, S. (2020). Mobilities in the Labyrinth: Pressuring the Boundaries of Women's Careers. Cadernos EBAPE.BR, 18 (spe), 757-769. Epub December 18, 2020. https://dx.doi.org/10.1590/1679. 395120190141

Guimarães, N. A. (2012). À procura de trabalho: uma boa janela para mirarmos as transformações recentes no mercado de trabalho? [Looking for work: a good window to look at recent changes in the labor market]. Novos Estudos Cebrap, (93), 123-143. https://doi.org/10.1590/S0101-33002012000200009

Gunz, H., \& Mayrhofer, W. (2015). The social chronology framework: A multiperspective approach to career studies. https://doi.org/10.2139/ssrn.2595568

Gunz, H., \& Mayrhofer, W. (2018). Rethinking career studies. facilitating conversation across boundaries with the social chronology framework. Cambridge, UK: Cambridge University Press.

Guo, L., Baruch, Y. (2020). The moderating role of a city's institutional capital and people's migration status on career success in China. Human Relations. https://doi.org/10.1177/0018726720946102

Hall, D. T. (1976). Careers in Organizations. Northbrook, IL: Scott Foresman.

Hall, D. T. (1996). Protean careers of the 21st century. Academy of Management Executive, 10(4), 8-16. https://doi.org/10.5465/ame.1996.3145315

Hall, D. T. (2004). The protean career: A quarter-century journey. Journal of Vocational Behavior, 65(1), 1-13. https://doi.org/10.1016/j.jvb.2003.10.006

Hofer, A., Straub, C., \& Spurk, D. (2021, July/August). The gig work phenomenon: Insights into current multidisciplinary research and trending topics. Annual Meeting of the Academy of Management, online, United States, 81 .

Ibarra, H., \& Obodaru, O. (2016). Betwixt and between identities: Liminal experience in contemporary careers. Research in Organizational Behavior, 36, 47-64. https://doi.org/10.1016/j.riob.2016.11.003

Instituto Brasileiro de Geografia e Estatística. (2018). Síntese de indicadores sociais: Uma análise das condições de vida da população brasileira. In Estudos e Pesquisas. Informação demográfica e socioeconômica (Vol. 39). Rio de Janeiro, RJ:

IBGE.

http://www.ibge.gov.br/home/estatistica/populacao/condicaodevida/indicadoresminimos/sinteseindicsociais 2010/SIS_2010.pdf

International Labour Organization. (2015). Education and labour markets: Analysing global patterns with the Key Indicators of the Labour Market (KILM). Geneva, SUI: ILO.

International Labour Organization. (2018a, October). Conceptual framework for statistics on the work relationships. International Conference of Labour Statisticians, Geneva, SUI, 20.

International Labour Organization. (2018b, February). Informality and non-standard forms of employment. G20 Employment Working Group. Buenos Aires, AR. Retrieved from https://www.ilo.org/wcmsp5/groups/public/m dgreports/-minst/documents/publication/wcms_646040.pdf

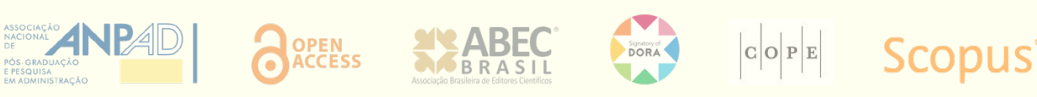


International Labour Organization. (2018c, October). Measurement of qualifications and skills mismatches of persons in employment. International Conference of Labour Statisticians, Geneva, SUI, 20.

Instituto de Pesquisa Econômica Aplicada. (2019). Mercado de Trabalho - IPEA. Carta de Conjuntura [Labor Market - IPEA - The Institute for Applied Economic Research. Letter of Situation], 45(4 trim.).

Janand, A. (2020). Three proposals for future career studies based on a Bergsonian approach of time and movement. EGOS Colloquium, 36.

Johnston, H., \& Land-Kazlauskas, C. (2018). Organizing on-demand: representation, voice, and collective bargaining in the gig economy. Geneva: ILO.

Kashyap, R., \& Bhatia, A. (2018). Taxi drivers and taxidars: A case study of Uber and Ola in Delhi. Journal of Developing Societies, 34(2), 169-194. https://doi.org/10.1177/0169796X18757144

Malik F., Wahaj Z. (2019) Sharing economy digital platforms and social inclusion/exclusion: A research study of Uber and Careem in Pakistan. In P. Nielsen, H. C. Kimaro. (Eds.), Information and communication technologies for development (pp. 248-259). ICT4D 2019. IFIP Advances in Information and Communication Technology, vol. 551. Springer, Cham. https://doi.org/10.1007/978-3-030-18400-1_20

Manyika, J., Lund, S., Bughin, J., Robinson, K., Mischke, J., \& Mahajan, D. (2016). Independent work: Choice, necessity, and the gig economy. Retrieved from https://www.mckinsey.com/featured-insights/employment-andgrowth/independent-work-choice-necessity-and-the-gig-economy\#

Mayrhofer, W., Meyer, M., \& Steyrer, J. (2007). Contextual issues in the study of careers. In K. Inkson \& M. L. Savickas (Eds.), Handbook of Career Studies (pp. 215-240). Sage. http://dx.doi.org/10.4135/9781412976107.n12

Nogueira, M. O., \& Zucoloto, G. F. (2017). Um pirilampo no porão: Um pouco de luz nos dilemas da produtividade e da informalidade no Brasil. Brasília, DF: IPEA.

Orlikowski, W. J., \& Yates, J. (2002). It's about time: Temporal structuring in organizations. Organization Science, 13(6), 684-700. https://doi.org/10.1287/orsc.13.6.684.501

Parasuraman, S., Greenhaus, J. H., \& Linnehan, F. (2000). Time, person-career fit, and the boundaryless career. Trends in organizational behavior, 7, 63-78. Retrieved from https://www.researchgate.net/publication/290807113_Time_person-career_fit_and_the_boundaryless_career

Peticca-Harris, A., DeGama, N., \& Ravishankar, M. N. (2018). Postcapitalist precarious work and those in the 'drivers' seat: Exploring the motivations and lived experiences of Uber drivers in Canada. Organization, 1-24. https://doi.org/10.1177/1350508418757332

Reilly, K. M. A., Lozano-Paredes L. H. (2019). Ride hailing regulations in Cali, Colombia: Towards autonomous and decent work (pp. 425-435). In P. Nielsen \& H. C. Kimaro. (Eds.). Information and communication technologies for development. ICT4D 2019. IFIP Advances in Information and Communication Technology, vol 551. Sage. https://doi.org/10.1007/978-3-030-18400-1_35

Reiss, L. K., Schiffinger, M., Mayrhofer, W., \& Rapp, M. (2020). Social inequalities in careers: Effects of social class origin and gender on career success. Academy of Management Proceedings, 2020(1). https://doi.org/10.5465/AMBPP.2020.17291abstract

Saunders, N. K. M. \& Townsend, K. (2016). Reporting and justifying the number of interview participants in organizational and workplace research. British Journal of Management, 27(4), 836-852. http://dx.doi.org/10.1111/1467-8551.12182

Schmidt, F. A. (2017). Digital labour markets in the platform economy: Mapping the political challenges of crowd work and gig work. Berlin, GER: Friedrich-Ebert-Stiftung.

Schultz, T. (1961). Investment in human capital. American Economic Review, 51(1), 1-17. https://www.jstor.org/stable/1818907

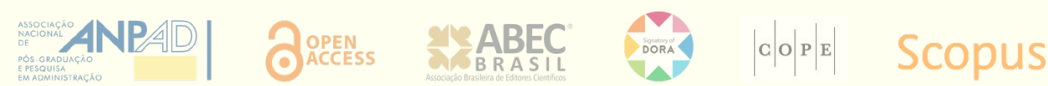


Sullivan, S. E., \& Baruch, Y. (2009). Advances in career theory and research: A critical review and agenda for future exploration. Journal of Management, 35(6), 1542-1571. https://doi.org/10.1177/0149206309350082

Sundararajan, A. (2016). The Sharing Economy. Cambridge, MSS: The MIT Press.

Tran, H., Baruch, Y., \& Bui, H. T. M. (2019). On the way to self-employment: The dynamics of career mobility. The International Journal of Human Resource Management. https://doi.org/10.1080/09585192.2019.1640267

Valenduc, G., \& Vendramin, P. (2016). Work in the digital economy: Sorting the old from the new. Brussels, BE: ETUI.

Valente, E., Patrus, R. \& Guimarães, R. C. (2019), Sharing economy: Becoming an Uber driver in a developing country. Revista de Gestão, 26(2), 143-160. https://doi.org/10.1108/REGE-08-2018-0088

Vinkenburg, C. J., Van Engen, M. L., \& Peters, P. (2015). Promoting new norms and true flexibility: Sustainability in combining career and care. In A. De Vos, \& B. I. J. M. Van Der Heijden. (Eds.), Handbook of research on sustainable careers (pp. 131-145). Cheltenham, UK: Edward Elgar Publishing.

Walker, M., Fleming, P., \& Berti, M. (2021). 'You can't pick up a phone and talk to someone': How algorithms function as biopower in the gig economy. Organization, 28(1), 26-43. https://doi.org/10.1177/1350508420978831

Waters, L., Briscoe, J. P., Hall. D. T., \& Wang, L. (2016). Protean career attitudes during unemployment and reemployment: A longitudinal perspective. Journal of Vocational Behavior, 84(3), 405-419. https://doi.org/10.1016/j.jvb.2014.03.003

Wood, A. J., Lehdonvirta, V., \& Graham, M. (2018). Workers of the Internet unite? Online freelancer organisation among remote gig economy workers in six Asian and African countries. New Technology, Work and Employment, 33(2), 95-112. https://doi.org/10.1111/ntwe.12112 


\section{Authors' contributions}

1st author: conceptualization (equal), formal analysis (equal), investigation (equal), methodology (equal), project administration (equal), writing-original draft (equal), writing-review \& editing (equal).

$2^{\text {nd }}$ author: conceptualization (equal), formal analysis (equal), project administration (equal), supervision (equal), writing-original draft (equal).

$3^{\text {rd }}$ author: conceptualization (equal), data curation (equal), project administration (equal), supervision (equal).

\section{Authors}

\section{Marcia Cristiane Vaclavik*}

Universidade Federal do Rio Grande do Sul, Escola de Administração

Rua Washington Luis, n. 855, Centro Histórico, 90010-460, Porto Alegre, Rio Grande do Sul mcvaclavik@gmail.com

(iD) https://orcid.org/0000-0003-4209-1054

\section{Sidinei Rocha-de-Oliveira}

Universidade Federal do Rio Grande do Sul, Escola de Administração

Rua Washington Luis, n. 855, Centro Histórico, 90010-460, Porto Alegre, Rio Grande do Sul sidroliveira@hotmail.com

(iD) https://orcid.org/0000-0001-9139-2684

\section{Andrea Poleto Oltramari}

Universidade Federal do Rio Grande do Sul, Escola de Administração

Rua Washington Luis, n. 855, Centro Histórico, 90010-460, Porto Alegre, Rio Grande do Sul andreaoltr@gmail.com

(iD) https://orcid.org/0000-0002-5897-2772

* Corresponding author

Peer review is responsible for acknowledging an article's potential contribution to the frontiers of scholarly knowledge on business or public administration. The authors are the ultimate responsible for the consistency of the theoretical references, the accurate report of empirical data, the personal perspectives, and the use of copyrighted material.

This content was evaluated using the double-blind peer review process. The disclosure of the reviewers' information on the first page is made only after concluding the evaluation process, and with the voluntary consent of the respective reviewers. 